\title{
HINDOE-EGGENOTE, WEET JY WAT JOU REGSPOSISIE IN DIE SUID-AFRIKAANSE REG IS?*
}

\author{
SIJ Cordier \\ LLB LLM \\ Student
}

Noordwes-Universiteit, Potchefstroomkampus

C Rautenbach

Bluris LLB LLM LLD

Professor in die Regte

Noordwes-Universiteit, Potchefstroomkampus

\section{SUMMARY}

This article investigates the legal position of a Hindu wife married in terms of Hindu rites. In general, her marriage is not recognised as a valid marriage because it does not comply with the requirements set out in the Marriage Act 25 of 1961. Although the Durban and Coast Local Division of the High Court recently held that she is a "spouse" in terms of the Intestate Succession Act 81 of 1987, her legal position is far from certain. In Singh $v$ Rampersad 20073 SA 445 (D) the court held that a monogamous marriage in terms of Hindu rites is not a valid marriage in terms of South African law. The non-recognition of her marriage has certain consequences, especially when a Hindu wife wants to dissolve her "marriage" or one of the "spouses" dies. In this contribution the differences between a Hindu marriage and a civil marriage are pointed out, including the possible consequences if parties want to conclude a marriage in terms of Hindu rites only.

\section{INLEIDING}

Die Suid-Afrikaanse bevolking is saamgestel uit verskeie kulturele en godsdienstige groepe, byvoorbeeld Hindoes, Moslems en Jode. Sommige van hierdie groepe het hulle eie nie-staatlike regstelsels ${ }^{1}$ waarvolgens hulle

Hierdie bydrae is 'n verwerking van 'n gedeelte van die eerste outeur se LLM-Boedelregskripsie (Noordwes-Universiteit, Potchefstroomkampus) met die titel Boedelbeplanning vir die Hindoevrou in Suid-Afrikaanse Konteks (2007).

Volgens Du Plessis Inleiding tot die Reg (1992) 200 is staatlike reg daardie reg wat van die staatsowerheid afkomstig is en waaraan alle Suid-Afrikaanse burgers gebonde is. Niestaatlike reg is daardie reg wat in ' $n$ ander sosiale instelling as eiesoortige interne reg geld. Die reg is egter nie van die staatsowerheid (wetgewer of hof) afkomstig nie en word gevolglik nie in Suid-Afrika as reg erken nie. Kerke het bv hulle eie kerkreg en klubs het hulle eie reëls. Hierdie reëls vertoon na hulle aard, struktuur en effek presies dieselfde 
daagliks in die private sfeer leef. ${ }^{2}$ Artikel 15(3) van die Grondwet $^{3}$ maak voorsiening vir die statutêre erkenning van ander regstelsels gebaseer op godsdiens of kultuur. Ten spyte van hierdie bepaling het die wetgewer tot op datum nog geen wetgewing gepromulgeer wat erkenning aan ander kulturele of godsdienstige regstelsels verleen nie. ${ }^{4}$

Die Suid-Afrikaanse Regshervormingskommissie het ondersoek na die erkenning van Moslemhuwelike ingestel, ${ }^{5}$ maar die aanbevelings van die Regshervormingskommissie is tot op datum hiervan nog nie in wetgewing opgeneem nie. Die regsposisie ${ }^{6}$ is steeds dat huwelike aangegaan kragtens ' $n$ godsdienstige regstelsel en wat nie aan die vereistes ${ }^{7}$ van die Huwelikswet voldoen nie, ongeldig is. ${ }^{8}$

Die nie-erkenning van huwelike aangegaan kragtens 'n nie-erkende godsdienstige of kulturele regstelsel, asook die feit dat ' $n$ vrou getroud binne een van hierdie regstelsels nie volgens die Suid-Afrikaanse reg kan skei nie ${ }^{9}$ hou uiters nadelige gevolge vir 'n vrou getroud binne een van hierdie regstelsels in. ${ }^{10}$ Daar word heelwat aandag in die literatuur aan die regsposisie van Moslemgades geskenk, maar tot dusver het die regsposisie van die Hindoe-eggenote weinig aandag geniet. Byvoorbeeld, gades getroud

kenmerke as die reg wat in die staat geld. Volgens Van Niekerk "Regspluralisme" in Bekker, Rautenbach en Goolam (eds) Inleiding tot Regspluralisme in Suid-Afrika (2006) 8-15 sluit nie-staatlike reg ook daardie regreëls in wat nie-amptelik deur godsdienstige gemeenskappe, soos Hindoes, nageleef word.

2 Van Niekerk 5

3 Grondwet van die Republiek van Suid-Afrika, 1996 (hierna "die 1996 Grondwet").

4 Die wetgewer het wel met die Wet op die Erkenning van Gebruiklike Huwelike 120 van 1998 erkenning aan huwelike aangegaan volgens die Afrika gewoontereg verleen, maar hierdie aspek is irrelevant vir doeleindes van hierdie bespreking.

5 Sien South African Law Reform Commission Project 59 on Islamic Marriages and Related Matters (2003).

$6 \quad$ Logee $v$ Minister of Interior 19512 SA 595 (T); Seedat's Executors v The Master (Natal) 1917 AD 302; and Ismail v Ismail 19831 SA 1006 (A).

7 Die huwelik moet deur 'n huweliksbevestiger, soos benoem ingevolge a 3 van die Huwelikswet 25 van 1961 (hierna "die Huwelikswet"), bevestig word en die huwelik moet ingevolge a 29A van die Huwelikswet geregistreer word.

8 Robinson, Human en Boshoff Inleiding tot die Suid-Afrikaanse Familiereg (2002) 248. In Kalla $v$ The Master 19951 SA 261 het die hof verduidelik dat die rede vir die nie-erkenning is dat godsdienstige huwelike potensieel poligamies van aard is. Daar kan egter gevra word of hierdie argument na die inwerkingtreding van die Wet op die Erkenning van Gebruiklike Huwelike 120 van 1998 sal water hou. Laasgenoemde Wet verleen in a 2 erkenning aan poligame gewoonteregtelike huwelike. Alhoewel argumenteer kan word dat huwelike aangegaan kragtens ' $n$ godsdienstige regstelsel erkenning behoort te geniet sal die argument vir erkenning nie in hierdie studie bespreek word nie.

9 Singh v Ramparsad 20073 SA 445 (D) (hierna "die Singh-gewysde"). In die Singh-gewysde het regter Patel geweier om 'n egskeiding aan 'n Hindoe-eggenote toe te staan. Hy verklaar in par [50] dat hy nie met godsdienstige kwessies gaan inmeng en sodoende lede van die Hindoegemeenskap aanstoot gee nie. Hierdie beslissing hou verreikende gevolge vir 'n Hindoe-eggenote, getroud volgens die Hindoereg, in en 'n boedelbeplanner sal hierdie beslissing voor oë moet hou wanneer hy deur 'n Hindoe-eggenote vir die beplanning van haar boedel genader word. Sien ook die bespreking van die Singh-gewysde in Matlala "The Law Reports" 2007 De Rebus 33-34.

10 Alhoewel die nadelige gevolge op verskeie tipes godsdienstige en kulturele huwelike in Suid-Afrika van toepassing kan wees, sal daar in hierdie studie slegs op die Hindoeeggenote gefokus word. 
volgens die Moslemreg kan 'n eis instel vir die verlies van onderhoud as gevolg van die onregmatige dood; ${ }^{11}$ 'n Moslemvrou word geag 'n langslewende "gade" te wees vir die doeleindes van die Wet op die Onderhoud van Langslewende Gades $^{12}$ en die Wet op Intestate Erfopvolging. ${ }^{13}$

Dit is ' $n$ sosiale realiteit dat sommige families ook volgens die tradisionele Hindoereg leef. Van tyd tot tyd word enkele sake ook in regspraak gevind. In Singh $v$ Rampersad ${ }^{14}$ het die hof beslis dat ' $n$ monogame Hindoehuwelik nie as geldig beskou word nie, terwyl die hof in Govender $v$ Ragavayah ${ }^{15}$ beslis het dat ' $n$ Hindoe-weduwee wel as 'n gade in terme van die Wet Intestate Erfopvolging ${ }^{16}$ beskou kan word.

In hierdie bydrae gaan die Hindoe-eggenote se regsposisie geëvalueer word. Die regsgevolge wat by 'n siviele huwelik intree, gaan met die gevolge wat by 'n Hindoehuwelik intree, vergelyk word. Die nadeel wat sy kan ly weens die feit dat haar huwelik nie volgens die Suid-Afrikaanse reg erken word nie, gaan ondersoek word, asook die besondere gevalle waarin sy wel as 'n "gade" ingevolge die Suid-Afrikaanse reg beskou word. Hierdie ondersoek is veral belangrik om Hindoe-eggenotes op hulle benarde posisie in die Suid-Afrikaanse reg bedag te maak sodat hulle voorkomende maatreëls kan neem.

\section{GEVOLGE VAN NIE-ERKENNING VAN HINDOEHUWELIKE}

Wanneer partye 'n siviele huwelik in terme van die Huwelikswet sluit, tree sekere regsgevolge in. Dieselfde kan egter nie van 'n ongeregistreerde Hindoehuwelik gesê word nie. Die normale regsgevolge van só 'n huwelik is afwesig, behalwe as die huwelik as 'n putatiewe huwelik ${ }^{17}$ beskou kan word.

Amod v Multilateral Motor Vehicle Accident Fund 19994 All SA 421 (HHA).

1227 van 1990 (hierna "die Wet op die Onderhoud van Langslewende Gades").

1381 van 1987 (hierna "die Wet op Intestate Erfopvolging"). Die Konstitusionele Hof het in Daniels v Campbell 20047 BCLR 735 (KH) (hierna "die Daniels-gewysde") beslis dat die langslewende gade in 'n monogame Moslemhuwelik as 'n "gade" ingevolge die Wet op Intestate Erfopvolging en as "langslewende" ingevolge die Wet op die Onderhoud van die Langslewende Gade kwalifiseer. Die Hooggeregshof het in Khan v Khan 20052 SA 272 (T) laasgenoemde posisie ook op poligame Moslemhuwelike van toepassing gemaak.

1420073 SA 445 (D).

[2008] JOL 22653 (D)

1681 van 1987.

17 Die leerstuk van die putatiewe huwelik het tot gevolg dat die gevolge van huwelike wat nietig is, verlig word. Kinders gebore uit só 'n huwelik word as binne-egtelik beskou en die huwelik is, in die afwesigheid van 'n huweliksvoorwaardekontrak, binne gemeenskap van goedere. 'n Huwelik word beskou as 'n putatiewe huwelik indien albei partye onbewus was van die gebrek wat die huwelik nietig maak en die vormvoorskrifte van die plek waar die huwelik voltrek is, nagekom is. Sien Robinson, Human en Boshoff 83-84 in hierdie verband. ' $n$ Hindoe-eggenote kan dus slegs aanspraak maak daarop dat sy 'n putatiewe huwelik gesluit het indien sy aan bogenoemde vereistes voldoen het. Die howe het in die verlede Moslemhuwelike as putatiewe huwelike verklaar. Rautenbach, Goolam en Moosa "Grondwetlike Uitleg" in Bekker, Rautenbach en Goolam (eds) Inleiding tot Regspluralisme in Suid-Afrika (2006) 159 verwys na Solomons v Abrahams 19914 SA 437 (W) waarin die hof geweier het om 'n Moslemhuwelik tot 'n putatiewe huwelik te verklaar omdat die hof slegs 'n "huwelik" gesluit ingevolge die Huwelikswet as geldig geag het. 'n Hindoe-eggenote 


\section{Onderskeid tussen siviele en Hindoehuwelike}

'n Siviele huwelik, dit wil sê 'n huwelik gesluit in terme van artikel 3 van die Huwelikswet, skep 'n regsverhouding tussen die gades wat tot sekere regte en verpligtinge aanleiding gee. Enkele van hierdie regsgevolge word vervolgens bespreek.

\section{Wedersydse onderhoud: ${ }^{18}$}

Vanaf huweliksluiting ontstaan 'n wedersydse (oor-en-weer) onderhoudsverpligting tussen die gades ongeag of die huwelik binne of buite gemeenskap van goedere gesluit is. ${ }^{19}$ Die onderhoudsverpligting rus op die gades in verhouding tot hulle afsonderlike vermoëns en inkomste. ${ }^{20}$ Waar die huwelik binne gemeenskap van goedere is, is die gades gesamentlik en afsonderlik aanspreeklik vir skulde aangegaan in belang van die gemeenskaplike huishouding. Waar die huwelik buite gemeenskap van goedere is, word daar onderskei tussen die periode voor en na die inwerkingtreding van die Wet op Huweliksgoedere. ${ }^{21}$ Ongeag of die huwelik voor of na die inwerkingtreding van die wet voltrek is, geld die reël dat die partye pro rata in verhouding tot hulle afsonderlike vermoëns onderhoudspligtig is. ${ }^{22}$ Artikels $23(1)$, (2) en (3) van die Wet op Huweliksgoedere bepaal dat 'n onderlinge regresreg tussen gades, getroud buite gemeenskap van goedere, bestaan waar een gade meer tot die gemeenskaplike huishouding bygedra het as waartoe hy of sy verplig was. ${ }^{23}$

Daar is regtens geen verpligting in terme van die Suid-Afrikaanse reg op die Hindoe-eggenoot om sy vrou te onderhou nie. 'n Hindoe-eggenote kan gevolglik ook nie haar "gade" verplig om tot die gemeenskaplike huishouding by te dra nie. Sy beskik ook nie oor 'n regresreg om die bedrag wat sy meer tot die huishouding bygedra het as wat sy moes, terug te eis nie. Die vraag ontstaan of 'n Hindoe-eggenote in so 'n geval 'n verrykingseis ${ }^{24}$ teen die Hindoe-eggenoot sal hê vir daardie gedeelte wat sy meer tot die gemeenskaplike huishouding bygedra het as wat sy moes. Dit wil egter voorkom

sal gevolglik nie op die feit dat haar huwelik 'n putatiewe huwelik is, kan steun om haar te "red" van die nadelige gevolge van die nie-erkenning van haar "huwelik" nie. Sien ook Barnard, Cronjé en Olivier Die Suid-Afrikaanse Persone- en Familiereg (1986) 279.

18 Sien Heystek $v$ Heystek 20022 SA 754 (T) vir 'n bespreking van die gedeelte verantwoordelikheid van beide gades vir die onderhoud van die gemeenskaplike huishouding. Volgens Sinclair The Law of Marriage (1996) 443 behels die wedersydse onderhoudsplig die verskaffing van huisvesting, voedsel, mediese benodigdhede en wat ook al die gades redelikerwys benodig.

19 Sinclair 442.

20 Barnard, Cronjé en Olivier 172.

2188 van 1984 (hierna "die Wet op Huweliksgoedere").

22 Robinson, Human en Boshoff 93.

23 Hierdie is die posisie vir gades wat na die inwerkingtreding van die Wet op Huweliksgoedere getroud is. Daar is geen verhaalsreg waar die gades na 1 November 1984 buite gemeenskap van goedere getroud is nie.

24 Een party sal ' $n$ verrykingseis teen 'n ander party instel indien eersgenoemde ten koste van laasgenoemde verryk is, terwyl laasgenoemde verarm is. 
asof die Hindoe-eggenote nie 'n verrykingseis sal hê nie, omdat die SuidAfrikaanse reg nie ' $n$ algemene verrykingsaksie erken nie. ${ }^{25}$

Daar kan geargumenteer word dat 'n Hindoe-eggenote se posisie vergelykbaar is met dié van partye wat in 'n saamleefverhouding ${ }^{26}$ betrokke is. ${ }^{27}$ In die afwesigheid van 'n ooreenkoms, waarin die partye gekontrakteer het om mekaar te onderhou, erken die Suid-Afrikaanse reg nie 'n onderhoudsplig tussen heteroseksuele "saambly"-lewensmaats nie. ${ }^{28}$ Die hof het in die Robinson-gewysde ${ }^{29}$ beslis dat die reg nie outomaties 'n onderhoudsplig op die "lewensmaats" gedurende die bestaan van die "life partnership" plaas soos in die geval van gades getroud ingevolge die Huwelikswet nie. Die ratio vir laasgenoemde is dat die reg nie verpligtinge op 'n persoon kan plaas waar die persoon duidelik bedoel het om nie sulke verpligtinge te onderneem nie.

\section{(b) Huishoudelike benodigdhede.30}

In die geval van 'n huwelik binne gemeenskap van goed word die aankoop van huishoudelike benodigdhede 'n gemeenskaplike las. Die gades is gesamentlik en afsonderlik teenoor derde partye vir die aankoop van huishoudelike benodigdhede aanspreeklik. ${ }^{31}$ Artikel 23(5) van die Wet op Huweliksgoedere bepaal dat die partye wat buite gemeenskap van goedere getroud is, gesamentlik en afsonderlik vir skulde ten opsigte van huishoudelike benodigdhede aanspreeklik is. Elke party is verplig om pro rata ooreenkomstig sy finansiële vermoë tot die aankoop van huishoudelike

25 Church en Heaton "Marriage" in LexisNexis Reference Works, Indexes, Dictionaries and Diaries par 12 (http://www.lexisnexis.co.za (Maart 2006)).

26 Volgens De Beer "Life Partnerships" in LexisNexis Forms and Precedents par 1 (http://www.lexisnexis.co.za (November 2004)) verwys die begrip "saamblyverhouding" na die situasie waar persone wat nie met mekaar getroud is nie, 'n verhouding het en saambly. Hierdie situasie toon baie van die eienskappe van 'n huwelik. Daar is verskeie woorde wat gebruik word om hierdie verhouding mee te beskryf, bv "domestic partnership", kohabitasie, saambly, konkibune of de facto-huwelik. Hierdie woorde is almal sinonieme wat gebruik word om een begrip, naamlik 'n "saamblyverhouding" te beskryf. Die begrip "saamblyverhouding" sal vir gerieflikheidsdoeleindes vir hierdie studie gebruik word. Saamblyverhoudings word, net soos Hindoehuwelike, nie in die Suid-Afrikaanse reg as huwelike erken nie. Sien Jazbhay "Domestic Life Partnership" 2005 De Rebus 26-28 vir 'n bespreking van die nie-erkenning van saamblyverhoudings.

27 Die howe se uitgangspunt by saamblyverhoudings is dat die partye wat die gevolge van die Huwelikswet op hul verhouding van toepassing wou maak, kon getrou het. Sien in hierdie verband Robinson v Volks NO 20046 SA 288 (KH) (hierna "die Robinson-gewysde"). Volgens Van der Merwe v Central Retirement Annuity Fund 20055 BPLR 463 (PFA) het die hof, in die Robinson-gewysde, die behoefte aan regsekerheid aangespreek deurdat 'n persoon sy sake ongesteurd en onafhanklik kan reël van persone aan wie hy nie 'n onderhoudsplig verskuldig is nie.

28 De Beer par 2. Sien ook Church en Heaton par 202.

29 Par [56].

30 Huishoudelike benodigdhede word in Robinson, Human en Boshoff 96 omskryf as enigiets wat redelikerwys benodig word vir die voeding, kleding, mediese behandeling en plesier van die lede van die huishouding. Volgens Sinclair 448 is huishoudelike benodigdhede enigiets wat insidenteel tot die bestuur van die gemeenskaplike huishouding is.

31 Robinson, Human en Boshoff 97. 
benodigdhede by te dra. ${ }^{32}$ Die individuele gade moet in ooreenstemming tot sy finansiële vermoë tot die aankoop van huishoudelike benodigdhede bydra. ${ }^{33}$ Elke gade het 'n regresreg teen die ander gade indien hy meer as sy finansiële vermoë toelaat tot die huishoudelike benodigdhede bygedra het. ${ }^{34}$

Omdat 'n Hindoehuwelik geen erkenning geniet nie, sal 'n Hindoeeggenote waarskynlik nie haar man verplig om tot die aankoop van huishoudelike benodigdhede by te dra nie. Dit hou veral nadelige gevolge in waar die Hindoe-eggenote, byvoorbeeld, 'n huisvrou is en sy huishoudelike benodigdhede op skuld moet aankoop. Sy kan haar man, na die aankope van die huishoudelike benodigdhede, nie vir die betaling van 'n gedeelte van die huishoudelike benodigdhede aanspreek nie (daar is geen gesag nie - dit volg logieserwys uit nie-erkenning).

Volgens Church en Heaton ${ }^{35}$ kan permanente saambly-lewensmaats wat kontrakte met derde partye vir die aankoop van huishoudelike benodigdhede sluit, voorgee dat hulle getroud is. In so 'n geval kan derde partye hulle op estoppe ${ }^{36}$ beroep om te voorkom dat een van die partye beweer dat hy nie vir die huishoudelike benodigdhede wat die ander lewensmaat aangekoop het, aanspreeklik is nie. Derdes sal hulle dus op estoppel kan beroep indien die Hindoe-eggenoot aanspreeklikheid vir die aankoop van die huishoudelike benodigdhede deur die Hindoe-eggenote ontken. Estoppel bied egter nie aan die Hindoe-eggenote 'n remedie nie. ${ }^{37}$

\section{(c) Remedies:}

Die Wet op Huweliksgoedere plaas sekere remedies tot 'n gade se beskikking ten einde te verhoed dat een gade ' $n$ ander gade benadeel. ${ }^{38} \mathrm{Die}$ hof kan, byvoorbeeld ${ }^{39}$ op aansoek van 'n gade, die onmiddellike verdeling van die gesamentlike boedel gelas waar die hof hom vergewis het dat die een gade die ander gade se belange wesenlik benadeel. ${ }^{40}$ Ingevolge artikel 16(2) kan die hof 'n gade se bevoegdheid om met die boedel te handel opskort. Daar is voorts ook gemeenregtelike remedies waar 'n gade as 'n

32 Visser en Potgieter Family Law (1994) 198.

33 King en Victor "Marriage Law and Planning" in LexisNexis Estate Planning (2006/2007) par 2.9 (http://www.lexisnexis.co.za (Maart 2006))

34 King en Victor (2006/2007) par 12.9.

35 Par 12.

36 Volgens Sonnekus Die Estoppelleerstuk in die Suid-Afrikaanse Reg (2000) 1 vind die estoppelleerstuk toepassing indien 'n persoon (die estoppelopwerper) weens die blaamwaardige skynverwekking deur sy teenparty (die estoppelontkenner) tot sy nadee gehandel het en laasgenoemde verhoed om op die verwekte skyn terug te gaan en die juisheid daarvan te ontken. Laasgenoemde is dus gebonde aan die skyn wat hy verwek het.

37 Daar kan geargumenteer word dat 'n Hindoe-eggenote haar in hierdie geval op verryking kan beroep.

38 Dit is die geval waar die gades binne gemeenskap van goedere getroud is.

39 Ingevolge a 20.

40 King en Victor Law and Estate Planning Easiguide (2006) 24. 
verkwister ${ }^{41}$ verklaar kan word, 'n interdik teen 'n gade verkry kan word ${ }^{42}$ of daar om boedelscheiding ${ }^{43}$ aansoek gedoen word. ${ }^{44}$

Artikel 8 van die Wet op Huweliksgoedere magtig 'n hof om die onmiddellike verdeling van die aanwas te gelas waar die gedrag van een gade die belange van 'n ander gade wesenlik benadeel, mits 'n derde party se belange nie hierdeur benadeel word nie. ${ }^{45}$ Hierdie remedie is reeds tydens die bestaan van die huwelik beskikbaar. ${ }^{46}$

'n Hindoe-eggenote is volkome kwesbaar deurdat daar geen van bogenoemde remedies tot haar beskikking is nie. Sy het geen seggenskap oor die wyse waarop haar "gade" met sy of hulle bates omgaan nie en sy kan hom nie keer indien hy dit op 'n roekelose wyse verkwis nie. ${ }^{47}$ 'n Moontlike probleem wat hier kan ontstaan, is dat die Hindoe-eggenoot op só 'n spandabelrige wyse met sy bates kan omgaan dat hy nie slegs sy "vrou" benadeel nie, maar dat daar ook nie genoeg geld is om vir onderhoud vir die minderjarige kinders, gebore uit die "huwelik", te voorsien nie.

\section{(d) Registrasie van eiendom:}

'n Gemeenregtelike woning hoef nie in die naam van beide die man en vrou, getroud binne gemeenskap van goedere, geregistreer te word nie. Beide gades is outomaties mede-eienaars van die eiendom indien die eiendom in een van die gades se name geregistreer is. Hierdie beginsel word duidelik in Ex parte Menzies ${ }^{48}$ geïllustreer. In laasgenoemde gewysde beslis die hof dat, waar die partye binne gemeenskap van goedere getroud was, en die huis slegs op die man se naam geregistreer was, die vrou outomaties as mede-eienaar van die huis in halwe onverdeelde aandele geag word. Selfs al was die huis nie in die vrou se naam geregistreer nie, kon sy daarop aanspraak maak. Die feit dat die partye binne gemeenskap van goed getroud was, het meegebring dat die vrou outomaties as mede-eienaar in onverdeelde en onverdeelbare halwe aandele van die huis beskou word.

Waar die gades egter buite gemeenskap van goedere getroud is en die eiendom slegs in een van die gades se naam geregistreer is, sal die ander

41 Davel en Jordaan Personereg (2002) 143 omskryf 'n verkwister as 'n persoon wat as gevolg van gebrek in sy oordeelsvermoë sy bates op 'n onverantwoordelike en roekelose wyse verkwis.

42 'n Interdik sal bv teen 'n gade wat dreig om die gemeenskaplike boedel op 'n onregmatige wyse te vervreem, verkry word. Sien Tel Peda Investigation Bureau Pty Ltd v Laws 19722 SA 1 (T); en Laws v Laws 19721 SA 321 (W) 323.

43 Kleyn De Boedelscheiding (1969) 7 omskryf die begrip Boedelscheiding soos volg: "Men verdeelt niet aandelen van deelgenoten, maar gemeenschappelijke goederen." Boedelskeiding is dus waar die onverdeelde aandele van mede-eienaars van gemeenskaplike goed tussen die mede-eienaars verdeel word.

44 Robinson, Human en Boshoff 133.

45 Dit is die geval waar die gades buite gemeenskap van goedere getroud is.

46 King en Victor (2006) 25.

47 Indien die man egter haar eie afsonderlike eiendom vervreem of vernietig, sal sy hom strafregtelik kan laat vervolg. Sien in hierdie verband Snyman Strafreg (2006) 539-542 vir die vereistes van saakbeskadiging.

$48 \quad 19933$ SA $799(K)$. 
gade geen aanspraak daarop hê nie. Hierdie beginsel is geïllustreer in Muswere $v$ Makanza ${ }^{49}$ waar die partye buite gemeenskap van goed getroud was en waar die huis slegs in die man se naam geregistreer was. Die man het sonder sy vrou se toestemming die eiendom aan 'n derde verkoop en na 'n ander gebied getrek. Die vrou het geweier om uit die huis te trek en die koper het om 'n uitsettingsbevel aansoek gedoen. Die hof het die uitsettingsbevel toegestaan en beslis dat die persoon wie se naam op die titelakte is prima facie as die eienaar van die grond erken word. Die hof beslis voorts dat, indien die huis in die man se naam geregistreer is, die vrou nie haar man kan verhoed om die huis of onroerende eiendom te verkoop nie, selfs al het sy direk tot die verkryging van die eiendom bygedra. ${ }^{50}$

Dit is duidelik dat 'n vrou wat buite gemeenskap van goedere getroud is, nie outomaties op mede-eiendomsreg van die huis kan aanspraak maak indien dit slegs op haar man se naam geregistreer is nie. ' $n$ Vrou wat binne gemeenskap van goedere getroud is, kan egter op mede-eiendomsreg van die huis aanspraak maak indien dit slegs op haar man se naam geregistreer is. Bogenoemde toedrag van sake is aan die regsgevolge wat outomaties by die onderskeie huweliksgoederebedelings intree, toe te skryf.

'n Hindoe-eggenote bevind haar wat die mede-eiendomsreg van onroerende eiendom betref, in dieselfde posisie as 'n vrou wat buite gemeenskap van goedere getroud is. Sy sal geensins aanspraak op onroerende eiendom wat slegs in haar man se naam geregistreer is, kan maak nie. Indien haar naam nie op die titelakte van die betrokke onroerende eiendom verskyn nie, sal sy nie soos haar eweknie wat binne gemeenskap van goedere getroud is, outomaties op die onroerende eiendom kan aanspraak maak nie. Indien 'n Hindoe-eggenote dus tot die koopsom van die huis bygedra het en sy haarself as mede-eienaar van die huis beskou, maar die huis slegs in haar "man" se naam geregistreer is, kan dit gebeur dat sy haar in 'n posisie soortgelyk as die eiseres in die Muswere-gewysde bevind. ' $n$ Hindoe-eggenote kan haar en haar kinders haweloos bevind indien haar man besluit om haar verlaat, die woonhuis slegs in sy naam geregistreer was, hy sedertdien die woonhuis aan 'n derde verkoop het en die derde om 'n uitsettingsbevel aansoek gedoen het.

492005 JOL 15978 (ZH) (hierna "die Muswere-gewysde").

50 Die feite in Sadiku $v$ Sadiku 2007 JOL 19342 (T) was soortgelyk deurdat die vrou in hierdie gewysde geweier het om uit die woning wat slegs in haar man se naam geregistreer was, te trek. Sy het beweer dat sy 'n mede-eienaar van die woning was omdat sy en haar man binne gemeenskap van goedere getroud was. Die hof gee toe dat die eiseres se eis slegs sou slaag indien sy kon bewys dat die gemeenskap van goedere op haar huwelik van toepassing was en dat sy gevolglik op mede-eienaarskap van die woning geregtig was. In hierdie geval was die gemeenskap van goedere egter uitgesluit omdat die eiseres ingevolge die reg van Nigerië getroud was. Laasgenoemde regstelsel erken nie die gemeenskap van goedere nie. 


\section{Regsgevolge by egskeiding}

\section{Algemeen}

'n Hindoe-eggenote sal geen regshulp van die Suid-Afrikaanse howe kan verwag indien haar man haar nie ingevolge die Hindoereg wil skei nie. In die Singh-gewysde het regter Patel onlangs in die Durbanse Hoë Hof geweier om 'n egskeiding aan 'n Hindoe-eggenote toe te staan. Hy het verklaar dat hy nie met godsdienstige kwessies wat lede van die Hindoegemeenskap kan aanstoot gee, gaan inmeng $n^{51}{ }^{51}$ en beslis dat dit nie binne die hof se bevoegdheid is om 'n egskeidingsbevel aan partye te verleen indien hulle gekies het om volgens 'n huweliksisteem te trou wat nie egskeiding in die vooruitsig stel nie. ${ }^{52}$ Hierdie beslissing hou verreikende gevolge in vir ' $n$ Hindoe-eggenote getroud volgens die Hindoereg.

\section{Boedelgroei en die Hindoe-eggenote}

In beginsel is dat gades, getroud binne gemeenskap van goedere, geregtig is op die helfte van die netto gemeenskaplike boedel by egskeiding. ${ }^{53}$ Hierdie beginsel is deur ' $n$ volbank van die Transvaalse Provinsiale afdeling in Corporate Liquidaters (Pty) Ltd $v$ Wiggil ${ }^{4}$ bevestig. Die hof kom tot die gevolgtrekking dat, waar 'n binne-gemeenskap-van-goedere huwelik deur egskeiding ontbind word, die dominium van elke gade se gedeelte van die gemeenskaplike boedel in die onderskeie gades op datum van egskeiding vestig. Die hof bevestig die Ex parte Menzies ${ }^{55}$-gewysde en beslis dat die registrasie van die eiendom nie 'n voorvereiste is vir die eiendom om in die onderskeie gades te vestig nie.

Ingevolge artikel 1(1) van die Wet op Egskeiding ${ }^{56}$ word 'n gade se "pensioenbelang" ook as deel van die gemeenskaplike boedel beskou en moet dit gevolglik ook by egskeiding verdeel word. ${ }^{5}$

Indien gades buite gemeenskap van goedere getroud is, behou elke gade sy of haar eie boedel. Die gades het egter sekere eise teen mekaar, byvoorbeeld verrekeningseise, ' $n$ eis ingevolge 'n skenkingsooreenkoms in die huweliksvoorwaardekontrak, of 'n aanwasvordering. ${ }^{58}$

' $n$ Hindoe-eggenote deel nie outomaties in die groei van haar man se boedel nie en indien sy 'n tuisteskepper was of 'n klein salaris verdien het, sal sy wesenlik benadeel word by die ontbinding van hulle "huwelik". Sy sal op geen wyse in die bates wat die gades saam tydens die bestaan van hulle

Singh-gewysde par [50]. Sien ook Matlala 2007 De Rebus 33-34.

Singh-gewysde par [51].

Robinson, Human en Boshoff 201

20072 SA $520(T)$.

19933 SA $799(K)$.

70 van 1979 (hierna "die Wet op Egskeiding").

57 A 2 is nie van toepassing waar die gades na 1 November 1984 getroud is onder ' $n$ bedeling wat die gemeenskap van goed, wins en verlies en die aanwasbedeling uitsluit nie.

58 Robinson, Human en Boshoff 205. 
"huwelik" bymekaar gemaak het en wat op die man se naam geregistreer is, kan deel nie. Indien sy tydens die huwelik ekonomies onaktief was, byvoorbeeld weens familieverpligtinge, of selfs waar sy haar man op indirekte wyse bygestaan het, sal sy op geen wyse in haar man se finansiële voorspoed kan deel nie. Sy sal ook nie kan aanspraak maak op haar man se pensioenbelang nie.

In Kirkland $v$ Kirkland ${ }^{59}$ het die hof beslis dat dit billik en regverdig sal wees indien die waarde van die partye gesamentlike boedel gelykop tussen die gades verdeel word. 'n Hindoe-eggenote sal egter nie, soos in Kirkland $v$ Kirkland gebeur het, op die helfte van haar man se bates kan aanspraak maak nie, omdat haar huwelik nie as 'n geldige huwelik in terme van die Wet op Huwelike of die Wet op Egskeiding beskou word nie. Sy sal ook nie sekere eise, byvoorbeeld 'n aanwaseis, soos haar eweknie wat buite gemeenskap van goedere getroud is, hê nie. 'n Hindoe-eggenote wat nie behoorlike boedelbeplanning gedoen het nie, sal dus bateloos agtergelaat word indien haar man haar verlaat. Sy sal voorts geen remedie om in die groei van haar man se boedel te deel hê nie.

\section{Verbeuring van huweliksvoordele}

Artikel 9 van die Wet op Egskeiding maak voorsiening dat een van die gades in 'n egskeidingsgeding by die hof kan aansoek doen om 'n bevel vir die verbeuring van vermoënsregtelike voordele deur die ander gade. Die hof kan so ' $n$ bevel toestaan indien die ander gade, in die afwesigheid van 'n verbeurdverklaringsbevel, onbehoorlik bevoordeel sal word. ${ }^{60}$

Hierdie remedie is nie tot ' $n$ Hindoe-eggenote se beskikking nie en sy sal nie by ' $n$ hof kan aansoek doen om verbeuring van vermoënsregtelike voordele nie, selfs al was haar "huwelik" kortstondig van aard en selfs al het haar "man" hom tydens die "huwelik" wesenlik wangedra. ${ }^{61}$

\section{Herverdeling van bates}

Indien die partye, buite gemeenskap van goedere met uitsluiting van die aanwasbedeling voor 1 November 1984 getroud is, het die hof ingevolge artikel 7 van die Wet op Egskeiding 'n diskresie om die bates op 'n billike wyse te verdeel. ${ }^{62}$ Die hof sal sy herverdelingsdiskresie, ingevolge artikel $7(4)$, slegs uitoefen indien die gade wat vir die herverdeling vra, gedurende die bestaan van die huwelik direk of indirek tot die instandhouding of groei van die ander gade se boedel bygedra het en dit op grond van sodanige bydraes "billik en regverdig" sal wees om die herverdelingsbevel toe te

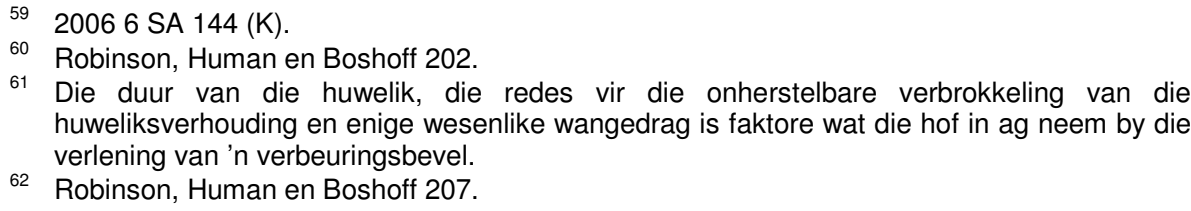


staan. ${ }^{63}$ In die verlede is die volgende tipe bydraes aanvaar: waar een gade sonder vergoeding in die ander gade se sakeonderneming gewerk het of waar een gade kostebesparing gedoen het deur huishoudelike verpligtinge vir die gemeenskaplike huishouding na te kom. ${ }^{64}$

Indien 'n Hindoe-eggenote voor 1 November 1984 volgens die Hindoereg "getroud" is en sy op 'n indirekte wyse tot die groei van haar man se boedel bygedra het gedurende die bestaan van hulle huwelik sal sy nie om 'n herverdelingsbevel kan aansoek doen nie. Sy gaan geensins vir die bydrae, hetsy direk of indirek wat sy gedurende die huwelik tot die groei van haar man se boedel gemaak het, vergoed word nie. Die nadelige posisie waarin 'n Hindoe-eggenote wat nie haar eie bates tydens die "huwelik" opgebou het nie, verkeer, is byna vanselfsprekend. Sy sal geen finansiële sekuriteit hê nie, en daar sal baie moeilik finansiële erkenning aan die bydraes wat sy tydens die "huwelik" in die vorm van tuisteskepping en omsien na die kinders gemaak het, verleen word.

\section{Onderhoud van die vrou}

Indien die hof nie 'n egskeidingsbevel ingevolge artikel 4 van die Wet op Egskeiding uitreik nie, volg dit dat die hof ook nie 'n onderhoudsbevel ingevolge artikel 7 ten gunste van die Hindoe-eggenote sal kan maak nie.

In Kooverjee $v$ Kooverje ${ }^{65}$ het die verweerderes deeltyds gewerk sodat sy in die middae na haar kinders kon omsien. Die hof het in hierdie geval rehabiliterende onderhoud ${ }^{66}$ aan haar toegestaan, welke onderhoud verminder sou word soos die kinders ouer en selfonderhoudend raak. Die rede hiervoor was om die verweerderes in staat te stel om haar primêre rol as versorger van die kinders te vervul. Dit is onwaarskynlik dat ' $n$ hof ' $n$ soortgelyke bevel in die geval van ' $n$ Hindoe-eggenote wat van haar man wil "skei", sal maak, want die partye kan nie volgens die Wet op Egskeiding "skei" nie. Die gevolg is dat die Hindoe-eggenote waarskynlik voltyds sal moet werk om haar rol as enkelmoeder te vervul. Die Hindoe-eggenote sal ook iemand moet aanstel om in die middae na haar kinders om te sien. Laasgenoemde bring natuurlik nadelige koste-implikasies mee.

Daar is egter regspraak wat as gesag vir die argument dat 'n hof 'n onderhoudsbevel ten gunste van 'n Hindoe-eggenote behoort te maak, kan dien. Byvoorbeeld in Khan $v K^{\prime} h^{67}$ het die Hof 'n onderhoudsbevel ten gunste van 'n gade in 'n poligame Moslemhuwelik gemaak. Die vraag wat in hierdie gewysde ontstaan het, uit hoofde van die bepalings van artikel 2(1)

Robinson, Human en Boshoff 208.

64 Robinson, Human en Boshoff 209.

6520066 SA $127(\mathrm{~K})$.

66 Robinson, Human en Boshoff 175 definieer "rehabiliterende onderhoud" as dié onderhoud wat gerig is op vrouens wat hulleself vir jare aan die huishouding en die opvoeding van die kinders gewy het. Die onderhoud stel die vrouens in staat om vir 'n betrekking opgelei of heropgelei te word. Dié onderhoud duur slegs vir die periode van opleiding.

6720052 SA 272 (T) (hierna "die Khan-gewysde"). Sien ook Schulze "Law Reports: Husband and Wife" 2005 De Rebus 42-43 vir 'n bespreking van die Khan-gewysde. 
van die Wet op Onderhoud, ${ }^{68}$ was of daar 'n regsplig op die appellant gerus het $^{69}$ om die respondent, met wie hy in ooreenstemming met die Moslemgebruike getroud was, te onderhou. Die hof beslis dat die voorwoord van die Wet op Onderhoud die vestiging van 'n billike onderhoudstelsel beklemtoon asook die fundamentele regte in die Grondwet. ${ }^{7}$ Die hof beslis voorts dat wanneer bepaal moet word of 'n spesifieke verhouding tot 'n onderhoudsplig lei die vraag gevra moet word of die applikant finansiële steun benodig en of die verhouding tussen die partye 'n onderhoudsplig skep. Die tye en die gemeenskap waarin ons leef, moet ook in ag geneem word. ${ }^{71}$ Daarbenewens is ' $n$ poligame familie ook ' $n$ tipe familie wat geregtig is op beskerming in die familiereg.

Die Hof verwys na die beslissing van die Konstitusionele Hof in Satchwell $v$ President of the Republic of South Africa ${ }^{72}$ waar laasgenoemde Hof selfs 'n onderhoudsbevel ten gunste van partye wat nie formeel getroud was nie, gemaak het. Die Hof het beslis dat die wedersydse onderhoudsplig van die wyse waarop ander mense die gades beskou het, afgelei kon word, van die vraag of die gades die familieverantwoordelikhede gedeel het en van die vraag of die gades vir mekaar by afsterwe voorsiening gemaak het. Die doel van familiereg in die algemeen is om kwesbare familielede te beskerm en om billikheid te verseker. ${ }^{73}$ Poligame huwelike is ook 'n verskyningsvorm van familie en moet deur die familiereg beskerm word. Poligame huwelike word deur die leerstellings van ' $n$ verskeie godsdienstige groepe, byvoorbeeld Moslems en Hindoes, aanvaar. ${ }^{74}$ Die openbare beleidsoorwegings en die interpretasie van wetgewing het met die inwerkingtreding van die Grondwet verander. Die doel van die Wet op Onderhoud sal gefrustreer word en nie bevorder word nie, indien die lede van 'n poligame huwelik van die beskerming wat laasgenoemde Wet bied, uitgesluit word, slegs omdat die regsvorm van hulle verhouding nie in ooreenstemming met die Huwelikswet is nie. $^{75}$ Die hof beslis ten slotte dat lede van 'n Moslemhuwelik, ongeag of dit monogaam of poligaam van aard is, op onderhoud geregtig is en dat die Moslem-egpaar binne die trefwydte van die Wet op Onderhoud val. ${ }^{76}$

Alhoewel 'n boedelbeplanner die Khan-gewysde en die Satchwellgewysde ter ondersteuning van sy of haar argument dat 'n hof 'n onderhoudsbevel ten gunste van 'n Hindoe-eggenote behoort te maak, kan gebruik, kan 'n boedelbeplanner nie sonder meer daarop staatmaak dat ' $n$ hof wel 'n onderhoudsbevel ten gunste van 'n Hindoe-eggenote sal maak nie. Behoorlike boedelbeplanning is daarom nodig. ${ }^{77}$

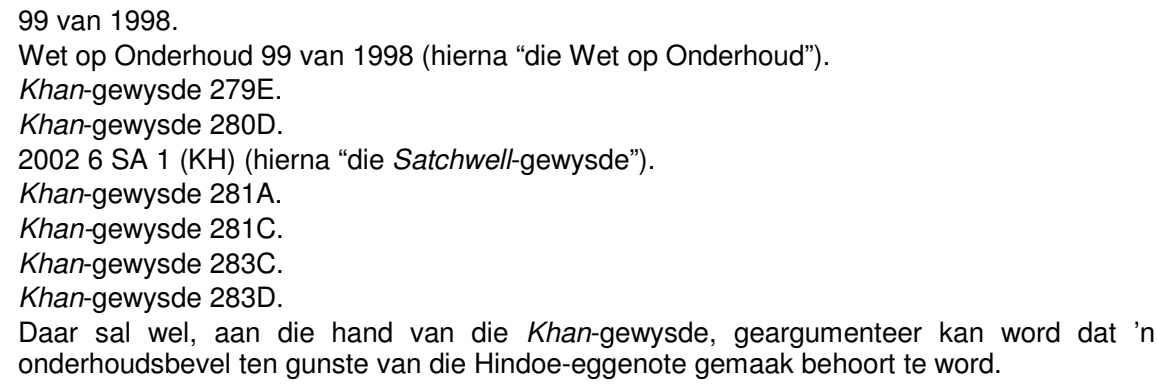




\section{Onderhoud ten opsigte van die afhanklike kind(ers)}

Een van die belangrikste kwessies is die vraag wat die posisie van minderjarige kinders, gebore uit 'n nie-erkende Hindoehuwelik, is. Ingevolge artikel 1(2) van die Wet op Registrasie van Geboortes en Sterftes ${ }^{78}$ word die kinders as binne-egtelik geag. Beide Hindoeouers het 'n gemeenregtelike verpligting om na hulle vermoë hulle afhanklike kinders te onderhou. ${ }^{79}$ Die Hindoe-eggenoot se bydrae tot onderhoud word deur die Hindoemoeder se lewenstandaard bepaal. Indien die Hindoe-eggenote 'n huwelik ingevolge die Huwelikswet met 'n ander man sou sluit, word die Hindoe-eggenoot se onderhoudsverpligting nie opgehef nie. ${ }^{80}$ Indien die Hindoe-eggenoot sou versuim om sy onderhoudsverpligtinge na te kom, is dit ingevolge artikel 31 van die Wet op Onderhoud, 'n misdryf en strafbaar met 'n boete of gevangenisstraf.

Waar die Hindoe-eggenoot vaderskap sou betwis, kan bloedtoetse uitgevoer word ten einde te bepaal of die Hindoe-eggenoot inderdaad die vader is. ${ }^{81}$

\section{Regsgevolge by die dood van een van die gades}

\section{Algemeen}

Indien die Hindoe-eggenoot intestaat sterf of sterf sonder dat die Hindoeeggenote behoorlike boedelbeplanning gedoen het, kan die Hindoeeggenote haarself in 'n benarde posisie bevind. Die probleme wat in so 'n geval kan ontstaan, sal voorts bespreek word.

\section{Die wyse van verdeling en die testament}

Die posisie by 'n siviele huwelik is soos volg: indien een van die gades wat binne gemeenskap van goed getroud was, sterf kom die gemeenskap van goed tot 'n einde en moet die gemeenskaplike boedel verdeel word. Die eksekuteur verdeel die netto waarde van die gemeenskaplike boedel in die helfte en betaal die een helfte oor aan die langslewende gade en die ander helfte vererf volgens die normale reëls van die erfreg. ${ }^{82}$

Indien een van die gades buite gemeenskap van goed getroud was en een van die gades sterf, gaan slegs die oorledene se boedel op die eksekuteur oor vir bereddering. ${ }^{83}$ Indien 'n Hindoe-eggenoot sterf, word sy boedel ingevolge die Suid-Afrikaanse erfreg vererf, tensy hy 'n testament

7851 van 1992

79 Robinson, Human en Boshoff 234. Hierdie plig word beklemtoon in artikel 15 van die Wet op Onderhoud.

80 Robinson, Human en Boshoff 234.

81 Sien Davel en Jordaan 103-108 vir 'n bespreking van die verskillende tipes bloedtoetse wat deur die Suid-Afrikaanse howe as getuienis van vaderskap erken word.

82 Robinson, Human en Boshoff 200.

83 Robinson, Human en Boshoff 205. 
opgestel het waarin hy aandui dat sy boedel volgens die Hindoereg moet verdeel. Indien 'n Hindoe-eggenoot sou versuim om laasgenoemde te doen, is die gevaar dat die Hindoe-eggenote volgens die Suid-Afrikaanse reg nie as die oorledene se "gade" beskou word nie, en dat sy gevolglik van erfopvolging uitgesluit word tensy haar naam uitdruklik in die teks van die testament genoem word. Dit word daarom aanbeveel dat sy by name as erfgenaam in die testament genoem word. ${ }^{84}$

\section{Wet op Onderhoud van Langslewende Gades ${ }^{85}$}

Die Wet op Onderhoud van Langslewende Gades het ten doel om vir ' $\mathrm{n}$ eis vir onderhoud aan die langslewende gade ${ }^{86}$ teen die boedel van die afgestorwe gade onder sekere omstandighede voorsiening te maak. Die betekenis van die terme "langslewende gade" is egter 'n omstrede kwessie en daar is verskeie regterlike interpretasies daaraan gegee.

In Kambule $v$ The Master ${ }^{87}$ beslis die hof dat die betrokke Wet wel nie die woorde "langslewende" of "huwelik" omskryf nie, maar dat 'n grondwetlik aanvaarbare definisie daarvan wel die partye van 'n gewoonteregtelike huwelik sal insluit indien bewys kan word dat die huwelik geldig gesluit is. In hierdie saak is die vereiste van geldigheid dus voorop gestel.

Hierdie benadering word ook in die algemeen deur die meeste howe gevolg; daar word normaalweg van die uitgangspunt uitgegaan dat die langslewende gade 'n gade in 'n huwelik wat deur die Suid-Afrikaanse reg as 'n geldige huwelik erken word, moes gewees het. ${ }^{88}$

Die Konstitusionele Hof het in die Daniels-gewysde ${ }^{89}$ die begrip "langslewende" uitgebrei om partye in 'n monogame Moslemhuwelik by die omskrywing van die Wet op Onderhoud van Langslewende Gades in te sluit. Die hof beslis dat die historiese uitsluiting van Moslems nie aan howe wat die gewone betekenis aan "langslewende" heg, toe te skryf is nie, maar eerder die gevolg is van 'n taalkundige beperking van die begrip "langslewende" wat uit 'n kulturele en rassistiese benadering vloei. ${ }^{90}$ Die hof beslis voorts dat die diskriminerende interpretasie nie langer in die lig van die Grondwet houdbaar is nie. Die grondwetlike waardes van gelykheid,

84 Rautenbach "Hindoe Erfreg" in Bekker, Rautenbach en Goolam (red) Inleiding tot Regspluralisme in Suid-Afrika (2006) 300-301.

8527 van 1990 (hierna "die Wet op Onderhoud van Langslewende Gades").

86 Die Onderhoudswet omskryf "langslewende gade" as die "langslewende in 'n huwelik wat deur die dood ontbind is".

8720073 SA 403 (O) 413 (E) 413-414.

88 Daniels v Campbell 20039 BCLR 969 (K) (hierna "die Daniels-gewysde"). Sien Rautenbach en Goolam "The Legal Status of a Muslim Wife under the Law of Succession: Is She still a Whore in terms of South African Law?" 2004 Stell LR 369-388; Mpuru "Law Reports: Law of Succession: Constitutionality" 2005 Codicillus 86-87; en De Villiers "Daniels v Campbell NO and Others: Case Review" 2003 ESR Review 8-10 vir 'n bespreking van die Danielsgewysde.

89 Sien Khan v Khan 20052 SA 272 (T) waar die Daniels-gewysde bespreek is en Nzimande $v$ Nzimande 20051 All SA 83 (W) waar daar na die Daniels-gewysde verwys is.

90 Par [19] 341E-342B. 
verdraagsaamheid en respek vir verskeidenheid vereis dat 'n wye en insluitende interpretasie aan die woord "langslewende" gegee moet word. ${ }^{91}$

Die howe het die begrip "langslewende" tot op datum nog nie na 'n Hindoe-eggenote in 'n nie-erkende Hindoehuwelik uitgebrei nie. Alhoewel daar, aan die hand van die Daniels-gewysde, geargumenteer kan word dat 'n Hindoe-eggenote in 'n monogame Hindoehuwelik haar in dieselfde posisie as ' $n$ Moslemvrou in 'n monogame Moslemhuwelik behoort te bevind, kan die boedelbeplanner nie op die feit dat sy wel as 'n "langslewende" beskou gaan word, staatmaak nie, en moet die boedelplan op so 'n wyse opgestel word om vir die geval, waar sy nie as 'n langslewende gade beskou gaan word nie, voorsiening te maak.

Daar kan egter gevra word of die Hindoe-eggenote in dieselfde posisie as 'n vrou wat in 'n saamleefverhouding is, sal wees. Die meerderheid van die Konstitusionele Hof het in Volks NO v Robinson ${ }^{92}$ die houding ingeneem dat die voordele wat gades ingevolge die Wet op Onderhoud van Langslewende Gades verkry, ex lege uit 'n onderhoudsplig ontstaan wat gedurende die gades se leeftyd bestaan. Daar bestaan geen onderhoudsplig tussen saamleef-lewensmaats nie. Die hof het daarom geweier om die omskrywing van "langslewende" na "permanente saamleef-lewensmaats" uit te brei. Daar bestaan tans nie 'n ex lege-onderhoudsplig tussen Hindoegades nie. Die Konstitusionele Hof gaan van die standpunt uit dat die hof nie 'n onderhoudsplig na 'n party se afsterwe kan skep indien die onderhoudsplig nie tydens die partye se leeftyd bestaan het nie.

Die vraag ontstaan of die howe die omskrywing van "langslewende" sal uitbrei om partye in 'n poligame Hindoehuwelik in te sluit. Die Konstitusionele Hof het onlangs in Hassam $v$ Jacobs ${ }^{93}$ beslis dat partye in 'n poligame Moslemhuwelik wel as gades ingevolge die Wet op Onderhoud van Langslewende Gades beskou kan word, en dit kan geargumenteer word dat dit wel sinvol sal wees om dit ook uit te brei na Hindoelewensmaats. Indien die omskrywing van "langslewende" wel uitgebrei word om partye in 'n poligame Hindoehuwelik in te sluit, kan dit gebeur dat daar onvoldoende fondse in die bestorwe boedel van die Hindoe-eggenoot is om aan al die Hindoeweduwees en hulle kinders se eise te voldoen.

\section{Wet op Intestate Erfopvolging ${ }^{94}$}

Die hof het in die Govender-gewysde die omskrywing "gade" in die Wet op Intestate Erfopvolging uitgebrei om partye in 'n monogame Hindoehuwelik in te sluit. ${ }^{95}$ Die hof het die welbekende gelykheidstoets in Harksen $v$ Lane ${ }^{96}$

91 Par [19] op 341E-342B.

9220055 BCLR 446 (KH) (hierna "die Robinson-gewysde"). Sien ook Heaton "An Overview of the Current Legal Position Regarding Heterosexual Life Partnerships" 2005 THRHR 662670; Nomvela "Family Law: Cohabiting Partners" 2004 Codicillus 85-88; en Rajah "The Interpretation of 'Spouse' in Light of the Recent Majority Decision of the Constitutional Court in the Volks v Robinson Case: Legal Focus" 2005 Pensions World 6 8-10.

93 [2009] ZACC 19 gelewer op 15 Julie 2009 (op datum hiervan nog ongepubliseer).

9481 van 1987 (hierna "die Wet op Intestate Erfopvolging").

95 Sien par 1. 
gebruik om te bepaal of die uitsluiting van sekere kategorieë persone van die definisie van "gade" soos in die Wet op Intestate Erfopvolging ongrondwetlik is of nie, en tot die slotsom gekom dat dit wel was. Die hof was van oordeel dat dit nie nodig was om 'n oordeel oor die geldigheid van die partye se huwelik uit te spreek nie en dat daar genoeg steun is om te bevind dat daar genoeg steun was vir:

"the proposition that a spouse of a 'marriage' by Hindu rites may well have the religious "marriage contract" given some recognition by South African law for certain purposes".

Gevolglik is die Hindoeweduwee wel as 'n gade vir doeleindes van die Wet op Intestate Erfopvolging beskou. Die beslissing is verwelkom, maar die uitwerking daarvan was natuurlik beperkend; dit is 'n uitspraak van die Durban en Kus-Plaaslike Afdeling met beperkende uitwerking en geld ook nie in die geval waar die partye in 'n poligame huwelik betrokke was nie.

Onlangs het die Konstitusionele Hof in Hassam $v$ Jacobs ${ }^{97}$ beslis dat die omskrywing van "gade" in die Wet op Intestate Erfopvolging uitgebrei moet word om ook die gades van 'n poligame Moslemhuwelik in te sluit en daar bestaan dus geen rede waarom dit nie ook na poligame Hindoehuwelike uitgebrei kan word nie. Tog moet gades in poligame Hindoehuwelike bedag daarop wees dat die Wet op Intestate Erfopvolging nie noodwendig ook na hierdie tipes huwelike uitgebrei sal word nie.

\section{Eis vir verlies van onderhoud}

Die Appèlhof het in Amod $v$ Multilateral Motor Vehicle Accidents Fund ${ }^{88}$ die gemeenregtelike eis van verlies aan onderhoud ontwikkel om 'n Moslemweduwee, in 'n monogame de facto-Moslemhuwelik wie se man onregmatig gedood is, in te sluit. Die hof beslis dat die korrekte benadering nie is om te vra of die huwelik ingevolge die gemenereg erken word nie, maar om te vra of die oorledene onder 'n regsverpligting gestaan het om die appellant gedurende die bestaan van die "huwelik" te onderhou. Indien wel, word daar gevra of hierdie reg vir doeleindes van die afhanklike se eis vir verlies van onderhoud beskermingswaardig was. ${ }^{99}$ Die hof beslis voorts dat die boni mores van die gemeenskap, 'n benadering wat die onderhoudsplig voortspruitend uit Moslemhuwelike beskerm, sal ondersteun. ${ }^{100}$

Alhoewel 'n Moslemweduwee, na die Amod-beslissing, 'n eis vir die verlies aan onderhoud het, volg dit nie outomaties dat 'n Hindoeweduwee ook ' $n$ eis vir verlies aan onderhoud het nie. Dit word aanbeveel dat die Hindoe-eggenote boedelbeplanning doen om vir die situasie waar die man

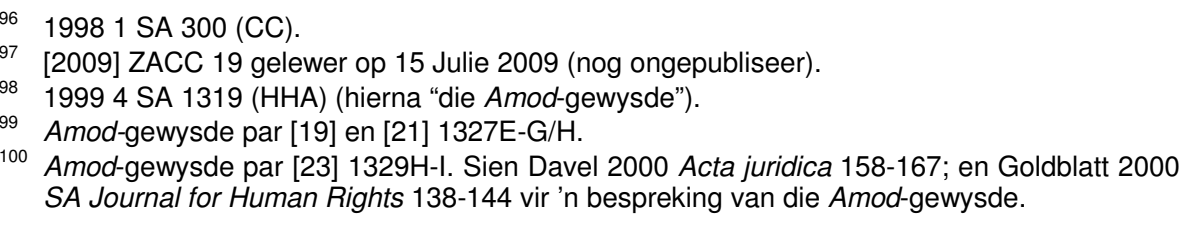


onregmatiglik gedood word en sy haar en haar kinders self moet onderhou voorsiening te maak.

\section{Pensioenfondsvoordele}

Die vraag ontstaan of 'n Hindoeweduwee op voordele ingevolge 'n pensioenfonds sal kan aanspraak maak wanneer haar "eggenoot" sterf. Die gevaar bestaan dat sy, omdat haar huwelik nie volgens die Suid-Afrikaanse reg erken word nie, op dieselfde wyse as 'n party wat in 'n saamleefverhouding betrokke is, beskou kan word. Die volgende voorbeelde dien ter illustrasie:

Die arbiter het in die geval van $D$ van der Merwe \& $M$ van der Merwe $v$ Central Annuity Fund \& S Fourie ${ }^{101}$ bevind dat mevrou Fourie wat saam met die oorledene gewoon het, nie as 'n "afhanklike" vir die fonds se doeleindes beskou kan word nie, ten spyte van die feit dat die oorledene haar as begunstigde genomineer het. Die arbiter bevind voorts dat mevrou Fourie nie as 'n afhanklike kan kwalifiseer nie omdat sy nie as 'n "gade" beskou word nie. Alhoewel dit duidelik was dat mevrou Fourie en die oorledene hulle finansiële hulpbronne saamgevoeg het, was dit volgens die arbiter nie voldoende om "feitelike afhanklikheid" vir die fonds se doeleindes daar te stel nie. ${ }^{102}$

Die arbiter in PH Maritz $v$ ABSA Groep Pensioenfonds ${ }^{103}$ het ook geweier om 'n saamwoon-lewensmaat van die oorledene as 'n afhanklike te beskou. Die klaer het in hierdie geval die grondwetlike geldigheid van die omskrywing van "gade" in die reëls van die fonds aangeveg. Die arbiter het bevind dat ' $n$ saamwoon-lewensmaat nie as 'n gade beskou kan word nie. Die arbiter het voorts bevind dat die omskrywing van "kwalifiserende gade", wat 'n saamwoon-lewensmaat uitsluit, nie die omskrywing van "kwalifiserende gade" in die reëls ongrondwetlik maak nie. ${ }^{104}$

In die lig van voormelde bespreking is dit duidelik dat 'n Hindoe-eggenote nie daarop kan staatmaak dat sy as ' $n$ afhanklike deur haar man se pensioenfonds beskou gaan word nie.

\section{Pactum successorium ${ }^{105}$}

Partye kan nie kontraktueel ooreenkom dat een party sy bates aan 'n ander party sal nalaat nie. Laasgenoemde staan bekend as 'n pactum

101 Ongepubliseerde beslissing verwys na in Rajah "Adjudicator Determinations and Court Cases" 2005 Insurance and Tax 18.

102 Rajah 2005 Insurance and Tax 20.

103 Ongepubliseerde beslissing verwys na in Rajah 2005 Insurance and Tax 21.

104 Rajah 2005 Insurance and Tax 22.

105 Bornmann v Potgietersrus Tabak Koop 19763 SA 488 (A) 501-503 defineer 'n pactum successorium as 'n ooreenkoms waarin die partye die vererwing (successio) van die nalatenskap (of 'n deel daarvan) of 'n bepaalde saak wat deel daarvan uitmaak) van een of meer van die partye na die dood (mortis causa) van die betrokke party reël. A en B kom bv met mekaar ooreen dat A sy nalatenskap (of ' $n$ deel daarvan) aan B sal bemaak. 
successorium en word in ons reg verbied. Waar die partye egter ingevolge die Suid-Afrikaanse reg getroud is, sal 'n skenking in 'n behoorlik geregistreerde huweliksvoorwaardekontrak 'n uitsondering op die verbod teen pacta successoria wees. ${ }^{106}$ 'n Egpaar, volgens die Suid-Afrikaanse reg getroud, kan dus wel in 'n huweliksvoorwaardekontrak ooreenkom om bates aan mekaar te bemaak. 'n Hindoe-egpaar se "huwelik" word egter nie in die Suid-Afrikaanse reg erken nie. Die Hindoe-egpaar kan daarom nie ooreenkom om bates aan mekaar te bemaak nie. Indien 'n Hindoe-egpaar in 'n kontrak sou sluit wat die bemaking van bates, na een van hulle se dood reël, kan dit op 'n ongeldige pactum successiorium neerkom. Die Hindoeegpaar sal dus op 'n ander wyse erfopvolging moet bewerkstellig.

\section{Boedelbelasting}

Gades wat getroud is ingevolge die Huwelikswet kan in hulle huweliksvoorwaardekontrak ooreenkom om 'n lewenspolis aan 'n gade te skenk. Só 'n skenking hou die voordeel in dat die opbrengs van die polis, ingevolge artikel 3(3)(a)(i) van die Boedelbelastingwet, ${ }^{107}$ van boedelbelasting vrygestel word. Aangesien Hindoegades nie 'n geldige huweliksvoorwaardekontrak kan sluit, sonder om 'n geldige huwelik ingevolge die Huwelikswet te sluit nie, is hierdie korting waarskynlik nie vir 'n Hindoe-eggenote se bestorwe boedel beskikbaar nie.

Alhoewel die Boedelbelastingwet sekere meganismes aan 'n Hindoeeggenote bied om die boedelbelasting betaalbaar op haar bestorwe boedel te verminder is daar ongelukkig, weens die feit dat haar huwelik nie in die Suid-Afrikaanse reg erken word nie, sommige gevalle waar sy met ander boedelbeplanningsmeganismes vorendag moet kom om die boedelbelasting wat op haar boedel by haar afsterwe betaalbaar gaan wees, te verminder. ${ }^{108}$

\section{Wetgewing waar 'n Hindoe-eggenote wel as 'n "gade" kwalifiseer}

Daar is sekere wetgewing in terme waarvan 'n Hindoe-eggenote wel as 'n gade beskou word. Hierdie wetgewing sluit in:

\section{(a)}

$$
\text { Insolvensiewet: }{ }^{109}
$$

'n Hindoe-eggenote word vir die doeleindes van die Insolvensiewet as 'n gade (oftewel eggenote) geag. Artikel 21(13) van die Insolvensiewet bepaal soos volg:

"In hierdie artikel beteken 'eggenoot' nie alleen 'n eggenote of eggenoot in die wettige sin nie, maar ook 'n eggenote of eggenoot kragtens 'n huwelik volgens

\footnotetext{
106 Ex parte Oosthuizen 19641 SA 174 (O); en Jordaan v De Villiers 19914 SA 396 (K).

10745 van 1955 (hierna "die Boedelbelastingwet").

108 Sien Cordier 34ev.

10924 van 1936.
} 
enige regstelsel of gebruik ${ }^{110}$ en ook 'n vrou wat met 'n man as sy eggenote leef of 'n man wat met 'n vrou as haar eggenoot leef, hoewel hulle nie met mekaar getroud is nie."

Die algemene insolvensieregreël is, dat waar die partye buite gemeenskap van goedere getroud is, die solvente gade se bates tydens die insolvente gade se sekwestrasie ingevolge artikel $21(1)^{111}$ van die Insolvensiewet eers op die Meester en daarna op die kurator oorgaan. Daar word dan met die bates gehandel asof dit deel van die insolvente gade se boedel vorm. ${ }^{112}$ Die doel van artikel 21 is om te verhoed dat gades in 'n poging om die skuldeisers van die insolvente boedel te benadeel saamspan. ${ }^{113}$ Die kurator sal slegs die solvente gade se goedere vrygee indien sy bewys dat haar bates in een van die kategorieë, gelys in artikel 21(2), ${ }^{114}$ tuishoort.

'n Hindoe-eggenote is wat die insolvensie van haar "eggenoot" betref, in dieselfde posisie as 'n vrou wat buite gemeenskap van goedere getroud is. Weens die feit dat 'n Hindoe-eggenote volgens die Insolvensiewet as 'n gade geag word, sal haar bates op die kurator van haar "eggenoot" se insolvente boedel oorgaan indien haar man insolvent verklaar word. 'n Hindoe-eggenote wat nie kan bewys dat die bates haar eiendom was onmiddellik voor haar "huwelik" met die Hindoe-eggenoot nie, sal haar bates kwyt wees. ${ }^{115}$ Dit is duidelik dat die feit dat die Hindoe-eggenote in hierdie geval as 'n gade beskou word, eerder 'n nadeel as 'n voordeel is.

\section{(b) Boedelbelastingwet: ${ }^{116}$}

\section{Die Boedelbelastingwet omskryf 'n "gade" as:}

"'n persoon wat op die tydstip van dood van bedoelde oorlede persoon die maat van daardie persoon was:

(a) in 'n huwelik of gewoonteverbintenis wat ingevolge die wette van die Republiek erken word;

(b) in 'n verbintenis wat jngevolge die leerstellings van enige godsdiens as 'n huwelik erken word.

'n Hindoe-eggenoot word dus as 'n gade in terme van hierdie Wet beskou en dit kan vir haar belastingimplikasies inhou.

110 Eie kursuvering.

111 Sharrock, Van der Linde en Smith Hockley's Insolvency Law (2005) 66. Vir die doeleindes van a 21 van die Insolvensiewet 24 van 1936 (hierna "die Insolvensiewet") word "gade" uitgebrei om 'n vrou of 'n man getroud volgens enige reg of gewoonte in te sluit.

112 Harksen v Lane NO 19981 SA 300 (KH) 302 (hierna "die Harksen-gewysde"); en Smith The Law of Insolvency (1988) 109.

113 Sharrock, Van der Linde en Smith 65; en Smith 108.

114 De la Rey Insolvency (1988) 167.

115 Die grondwetlikheid van a 21 is in die Harksen-gewysde aangeveg. Regter Goldstone beslis dat a 21 grondwetlik is en dat die doel van hierdie artikel is om te verseker dat die insolvente boedel nie ontneem word aan eiendom waarop dit in werklikheid geregtig is nie.

11645 of 1955.

117 Eie kursuvering. 


\section{(c) Ongevallewet: $:^{118}$}

Dit wil voorkom asof artikel 4(1)(b) van die Ongevallewet ruimte laat vir die Hindoe-eggenote om as ' $n$ "gade" te kwalifiseer. Artikel 4(1)(b) verleen wye diskresionêre magte aan die Kommissaris om te besluit wie as 'n afhanklike by die werknemer se dood kwalifiseer indien die vergoeding, verskuldig aan die werknemer se afhanklikes, toegeken moet word. Die subartikel bepaal dat, indien daar geen weduwee is, wat geheel of gedeeltelik, ten tye van die ongeval, van die werknemer vir lewensbehoeftes afhanklik was nie, enige vrou saam met wie die werknemer ten tye van die ongeluk geleef het, as ' $n$ afhanklike beskou sal word. Dit is dus wel moontlik dat 'n Hindoe-eggenote as "gade" ingevolge die Ongevallewet kan kwalifiseer. Die Kommissaris het ' $n$ diskresie in hierdie verband, en die Hindoe-eggenote kan nie daarop staatmaak dat sy verseker as 'n gade beskou gaan word nie.

$$
\text { Inkomstebelastingwet: }{ }^{119}
$$

Skenkings tussen gades word van belasting vrygestel. ${ }^{120}$ "Gade" word soos volg in die Inkomstebelastingwet gedefinieer:

“'gade' met betrekking tot enige persoon, die maat van sodanige persoon -

(a) in 'n huwelik of gewoonteverbintenis ingevolge die wette van die Republiek erken;

(b) in 'n verbintenis wat ingevolge die leerstellings van enige godsdiens as 'n huwelik erken word; of

(c) in 'n selfde-geslag of heteroseksuele verbintenis wat die Kommissaris oortuig is bedoel is om permanent te wees, ..."

Dit is duidelik volgens subartikel (b) dat 'n Hindoegade wel as ' $n$ gade in terme van die Inkomstebelastingwet beskou sal word. 'n Hindoe-egpaar kan dus van skenkings tussen gades as boedelbeplanningsmeganisme gebruik maak.

Die insluiting van partye wat volgens die leerstellings van enige godsdiens getroud is by die omskrywing van "gade", hou ook ander belastingimplikasies in. Die belastingonduikingsbepalings ${ }^{122}$ van die Inkomstebelastingwet kan dus ook op 'n Hindoe-egpaar van toepassing wees en die vrou sal moet sorg dra dat die boedelbeplanningsmeganismes wat sy in plek stel nie as belastingonduikingsbepalings geïnterpreteer word nie.

Artikel 7 is daargestel om die belastingontduiking tussen gades teë te werk. Indien 'n skenking gemaak word met die hoofoorweging om die

11830 van 1941 (hierna "die Ongevallewet").

11958 van 1962 (hierna "die Inkomstebelastingwet").

120 Meyerowitz "Meyerowitz on Income Tax" 2005/2006 The Taxpayer 31-8 tot 31-9.

121 Eie kursivering.

122 Volgens Jordaan, Koekemoer, Stiglingh, Van Schalkwyk, Wassermann en Wilcocks Silke: Suid-Afrikaanse Inkomstebelasting (2008) 541 verwys "belastingonduiking" na die onwettige aktiwiteite wat opsetlik deur 'n belastingbetaler onderneem word om homself van sy belastinglas te verlos. ' $n$ Voorbeeld van belastingontduiking is waar ' $n$ belastingbetaler inkomste weglaat van sy jaarlikse belastingopgawe. 
skenker se belastingaanspreeklikheid uit te skakel is artikel $7(2)$ van toepassing. Artikel 7(2) bepaal dat waar 'n belastingbetaler 'n skenking, skikking of ander vervreemding aan sy gade maak, en inkomste aan die gade as gevolg van die skenking haar toeval, die inkomste geag word die inkomste van die skenkende gade (die skenker) te wees.

Die feit dat ' $n$ Hindoe-egpaar as gades beskou word, hou ook belangrike kapitaalwinsimplikasies in. Ingevolge paragraaf 55 van die Agste Skedule van die Inkomstebelastingwet is ' $n$ bedrag, ontvang deur 'n persoon met betrekking tot 'n polis, nie aan kapitaalwinsbelasting onderhewig nie. Dit sal alleen geld indien die persoon wat die opbrengs van die polis ontvang, die gade van die oorspronklike begunstigde eienaar van die polis is. Die Hindoeegpaar sal waarskynlik hierdie kapitaalwinsvrystelling kan geniet indien hulle langtermynpolisse aankoop.

Daar word vir kapitaalwinsdoeleindes geag dat 'n persoon sy bates by sy afsterwe vervreem en dit lei tot die kapitaalwinsaanspreeklikheid van die bestorwe boedel. ${ }^{123}$ Indien die bates van die oorledene aan die langslewende gade nagelaat word, sal geen kapitaalwinsaanspreeklikheid ontstaan nie. Die kapitaalwinsaanspreeklikheid word uitgestel tot na die dood van die langslewende gade. ${ }^{124}$ Dit is raadsaam dat 'n Hindoeeggenote, wanneer sy die begunstigdes van die bates in haar boedel in haar testament aanwys, hierdie aspek in gedagte hou.

$$
\text { Wet op Hereregte: }{ }^{125}
$$

Die Wet op Hereregte omskryf "gade" as die maat van enige persoon:

(a) in 'n huwelik of gewoonteverbintenis ingevolge die wette van die Republiek erken;

(b) in 'n huwelik of gewoonteverbintenis wat ingevolge die leerstellings van enige godsdiens ingevolge die wette van die Republiek erken; ${ }^{12}$

(c) in 'n selfde geslag- of heteroseksuele verbintenis wat die Kommissaris oortuig is bedoel om permanent te wees.

Hierdie omskrywing het 'n belangrike invloed op die interpretasie en toepassing van die Wet op Hereregte. Artikel 9 stel enige eiendom wat die langslewende gade op enige wyse uit die oorledene gade se bestorwe verkry, van hereregte vry. Die woorde "op enige wyse" verwys na die verkryging ingevolge 'n testament of intestate erfopvolging. Indien 'n Hindoeeggenote eiendom van haar "man" erf, sal sy dus nie hereregte daarop hoef te betaal nie. Indien 'n Hindoe-eggenote eiendom aan haar "man nalaat, sal haar bestorwe boedel geen kapitaalwinsbelasting of hereregte daarop hoef te betaal nie. ${ }^{127}$

\footnotetext{
${ }^{123}$ Mhlongo "The Definition of Spouse: It's Impact on Tax Legislation" 2002 Insurance and Tax 25.

124 Mhlongo 2002 Insurance and Tax 26.

12540 van 1949 (hierna "die Wet op Hereregte").

${ }^{126}$ Eie kursivering.

${ }^{127}$ A 9 van die Wet op Hereregte en Agste Skedule van die Inkomstebelastingwet.
} 


\section{GEVOLGTREKKING EN AANBEVELINGS}

Dit is belangrik dat 'n Hindoe-eggenote kennis dra van die feit dat haar huwelik nie as geldig in die Suid-Afrikaanse reg beskou word nie, tensy die huwelik aan die vereistes van die Huwelikswet voldoen. Die nie-erkenning van haar huwelik hou belangrike regsimplikasies in, byvoorbeeld:

- Sy kan nie van haar man volgens die Suid-Afrikaanse reg skei nie.

- Daar rus geen onderhoudsverpligting op haar man om haar te onderhou of om tot die aankoop van die huishoudelike benodigdhede by te dra nie.

- Sy is remedieloos indien haar man tot nadeel van haar en hulle kinders se onderhoud, sy boedel verkwis.

- Indien die eiendom slegs in haar man se naam geregistreer is, kan sy nie daarop aanspraak maak nie.

- Sy deel nie outomaties in die groei van haar man se boedel tydens die huwelik nie.

- Sy kan nie vir die verbeuring van huweliksvoordele eis of dat artikel 7(4) van die Wet op Egskeiding moet toepassing vind nie.

- Sy sal waarskynlik na die ontbinding van hulle "huwelik" voltyds moet bly werk of werk probeer vind indien sy werkloos is, omdat die hof nie noodwendig 'n onderhoudsbevel ten gunste van haar sal maak nie.

- Sy sal waarskynlik nie testaat van haar man kan erf nie, tensy sy spesifiek by name in sy testament benoem is nie. Veral haar regsposisie met betrekking tot vererwing tussen meerdere eggenotes in 'n poligame familie kan onseker wees.

- Indien haar man sterf, kan dit gebeur dat daar onvoldoende fondse in sy boedel is om vir sy meerdere vroue en kinders se onderhoud voorsiening te maak.

- Sy sal moontlik nie ingevolge die Wet op Onderhoud van Langslewende Gades as 'n "gade" beskou word nie.

- Sy kan waarskynlik nie 'n eis vir verlies aan onderhoud instel indien haar man onregmatiglik gedood word nie.

- Daar bestaan 'n moontlikheid dat sy nie as 'n afhanklike van haar man se pensioenfonds beskou sal word nie.

- Indien die Hindoe-egpaar 'n ooreenkoms sluit ingevolge waarvan hulle mekaar oor en weer as erfgename aanwys, sal dit neerkom op 'n ongeldige pactum successorium.

- Artikel 3(3)(a)(i)-korting van die Boedelbelastingwet is waarskynlik nie tot die Hindoe-egpaar se beskikking nie.

Daar is egter sekere wetgewing in terme waarvan 'n Hindoe-eggenote wel as ' $n$ gade beskou word. Die feit dat 'n Hindoe-eggenote in sommige gevalle as 'n "gade" beskou word en in ander gevalle nie, kan voordelig of nadelig wees. Dit is nadelig in die geval van die Insolvensiewet waar die Hindoe- 
eggenote ' $n$ risiko loop om haar bates te verloor. Dit is voordelig in die geval van die Boedelbelastingwet omdat die meganisme van artikel 4(q) tot die Hindoe-eggenote se beskikking gestel word. Die Ongevallewet laat ruimte vir die moontlikheid vir 'n Hindoe-eggenote om as 'n "gade" te kwalifiseer.

Die feit dat 'n Hindoe-eggenote as 'n "gade" ingevolge die Inkomstebelastingwet beskou word, hou voor- en nadele in. Die voordeel is dat die Hindoe-egpaar kapitaalwinsvrystellings kan geniet. Die nadeel is dat die belastingonduikingbepalings op die Hindoe-egpaar van toepassing is. Indien 'n Hindoe-eggenote eiendom aan haar "eggenoot" nalaat, sal haar bestorwe boedel ingevolge die Wet op Hereregte geen hereregte op die oordrag van die eiendom betaal nie.

Dit kan gebeur dat 'n Hindoe-egpaar onkundig is met betrekking tot hulle regsposisie en gevolglik nie besef dat die nie-erkenning nadelige gevolge vir die vrou inhou nie, maar dit kan ook gebeur dat haar man mala fide die regsimplikasies van nie-erkenning verswyg. Dit word gevolglik aanbeveel dat Hindoe-eggenotes hulle deeglik van hulle regsposisie vergewis en behoorlike regsadvies inwin alvorens hulle 'n Hindoehuwelik sluit. Terwyl die erkenning van Hindoehuwelike in Suid-Afrika onseker bly, sal dit beter wees vir 'n vrou wat 'n Hindoehuwelik wil sluit, om daarop aan te dring dat die vereistes van die Huwelikswet wat geld ten opsigte van siviele huwelike, nagekom word, of dat alternatiewe boedelbeplanningsinstrumente aangewend word. $^{128}$

${ }^{128}$ Cordier $34 \mathrm{ev}$ bespreek verskeie inter vivos en mortis causa boedelbeplannings-instrumente wat deur die Hindoe-eggenote aangewend kan word. 